\title{
Need Analysis of Biology Modul as Learning Media Based on Project Based-Learning
}

\author{
Diana Susanti ${ }^{1,}$, , Liza Yulia Sari ${ }^{1}$, Vivi Fitriani ${ }^{1}$, Ramadhan Sumarmin ${ }^{2}$ \\ ${ }^{1}$ Department of Biology Education, Sekolah Tinggi Keguruan Ilmu Pendidikan Persatuan Guru Republik Indonesia, Sumatera Barat, Padang, \\ Indonesia \\ ${ }^{2}$ Department of Biology, Universitas Negeri Padang, Padang, Indonesia
}

Email address:

dianasusantimpd@yahoo.co.id (D. Susanti)

*Corresponding author

To cite this article:

Diana Susanti, Liza Yulia Sari, Vivi Fitriani, Ramadhan Sumarmin. Need Analysis of Biology Modul as Learning Media Based on Project Based-Learning. Education Journal. Vol. 8, No. 4, 2019, pp. 134-137. doi: 10.11648/j.edu.20190804.11

Received: May 7, 2019; Accepted: June 23, 2019; Published: July 9, 2019

\begin{abstract}
The subject of biology learning media discusses the understanding of the types, characteristics, and functions of instructional media, as well as determining, designing and in operational biological learning media that are in accordance with the characteristics of the junior and senior high school biological material. In the achievement of the material students have not been assisted by the right teaching materials, so they are less trained to make biology learning media that are used by teachers in the classroom. The porpose of this subject to look at the needs of lecturers and students in the development of learning media modules based on Project Based-Learning. This researched is developmental research using a 4D-model. In this researched is only at the define stage to analyze is the needs of lecturers and students in developing a biology learning media module based on project-based learning. Data is processed by descriptive analysis. The results showed that the analysis of the needs of lecturers and students towards the development of the Project Based-Learning module was on the criteria needed with the percentage of $66.67 \%$ and $76.25 \%$. It can be concluded that it need to develop Project Based-Learning module is needed by lecturers and students.
\end{abstract}

Keywords: Module, Project Based-Learning, Biology Learning Media

\section{Introduction}

Learning media is a subject that requires students to be creative in designing, producing and utilizing teaching materials. This course is the provision for students to become a professional teacher and able to take advantage of everything around to be used as a medium for learning. Media is designed and produced is only useful to help communication in learning, so students understand what is taught by the teacher. One of the functions of learning media according to Mukti and Nurcahyo [1] is teaching aids that help motivate, influence the climate, conditions, and learning environments arranged and created by teachers.

Theproblemofthissubjectsare, lecturers have not used teaching materials in printed. Lecturers only used power points and handouts when taught at the class in sheets. Sometimes there is no teaching material that helps students to design, produce and utilize the learning media in the classroom. So that the media produced by students in lectures is not optimal and it's not as expected in the actual learning conditions. Because the media in learning must be able to be a tool for delivering messages that students can use to understand the material being taught and can also increase student motivation. This argued is same with Athiyah [2] that using learning media can provide motivation for students to learn.

The solved of the problems, it takes a teaching material that is able to make students assemble, create and utilize learning media for biology learning material. One of them is by making teaching materials in the form of modules. Prastowo [3] said that the module is an independent learning package that includes a series of learning experiences that are planned and designed systematically to help students achieve learning goals. Modules are used to improve student activities and motivation in learning, especially biology 
learning. According to Sumarmin [4], modules can be used for biology lessons. Module is a solution to empower the students' critical thinking ability because the module is a level of activity, training, and self-assessment to monitor them a every level of student learning, and more potential means empowering critical thinking. This ability achieves maximum learning output [5]. The module functions as a learning tool that is independent, so students can learning dependently according to their respective speeds. According to Daryanto [6] the module can make students learning dependently. Because the lectures on biology learning media require students to design a media, the modules are developed with project based learning $(\mathrm{PjBL})$.

Project Based Learning is learning designed for complex problems in which students carry out investigations to understand it, emphasizing learning with long activities, assignments given to students are multidisciplinary, and product oriented [7]. PjBL learning is chosen as the basis for developing learning activities in the module because it can help train the ability of students to carry out meaningful learning when they become teachers [8]. Based on the presentation, it is clear that the model is based on learning is a learning model that is appropriate for learning activities, providing freedom to develop their potential [9]. Development of Project based learning modules based on physics learning media subjects has been developed by the Permadi [8] and e-modules are produced with very good validation results. In addition, research on the development of using PjBL was also conducted by Maiasputri [10] and the results were very valid.

\section{The Research Method}

This research is a development research using 4-D models, the stages in this study are define phase, by analyzing the needs of students, and lecturers on the need for modules developed. The sample in this study was 40 students and 2 lecturers of biology learning media. The questionnaire was modified by Sophia [11] with the criteria seen were the availability of teaching materials, the availability of learning modules, the desire to make modules, and PjBL.

Data is processed by the percentage formula proposed by Riduwan [12] as follows:

$$
\text { Valueofpercentage }=\frac{\text { scoreobtained }}{\text { maximumscore }} \mathrm{X} 100 \%
$$

The level of needs analysis uses the Riduwan, and Akdon classification [13] as in Table1.

Table 1. Criteria for Module Requirements.

\begin{tabular}{lll}
\hline Percentage (\%) & Activitiescriteria & Conversion \\
\hline $81-100$ & Very high & Very Need \\
$61-80$ & High & Need \\
$41-60$ & Midle & Need Enough \\
$21-40$ & Low & Not Need \\
$1-20$ & Very Low & Very Not Need \\
\hline
\end{tabular}

\section{Result}

The analysis of the needs of PJBL-based biology learning media modules that have been processed from lecturers, and students showed that the results of lecturers, and students need project based learning biology media modules to be developed. The details of the result obtained from lecturers, and students are as followed.

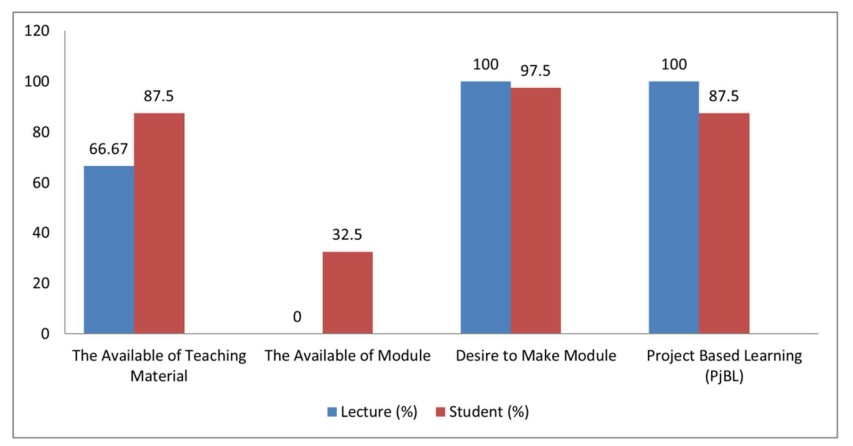

Figure 1. Analysis of Module Requirements for Biology Learning Media Based on Project Based Learning (PjBL).

The results of the needs of lecturers and students as a whole can be seen from the following Table.

Table 2. Analysis of Module Requirements for Biology Learning Media Based on Project Based Learning (PjBL).

\begin{tabular}{|c|c|c|c|}
\hline No & Indicators & Lecture (\%) & Student $(\%)$ \\
\hline 1 & $\begin{array}{l}\text { The Available of Teaching } \\
\text { Material }\end{array}$ & 66.67 & 87.5 \\
\hline 2 & The Available of Module & 0 & 32.5 \\
\hline 3 & Desire to Make Module & 100 & 97.5 \\
\hline 4 & Project Based Learning (PjBL) & 100 & 87.5 \\
\hline \multicolumn{2}{|c|}{ Total } & 266.67 & 305 \\
\hline \multicolumn{2}{|c|}{ Range } & 66.67 & 76.25 \\
\hline
\end{tabular}

Based on the Table 2 above need for biology learning media modules based on project based learning is needed by lecturers, and students. It can help lecturers in explaining the material and helping students to understand and create a good biology learning media.

\section{Discussion}

Based on the Figure 1, the need for developing PjBL based biology learning media modules is needed. Viewed from the aspect of the availability of teaching materials with an average value of $66.67 \%$ of lecturers and $87.5 \%$ of students it appears that lecturers and students have used teaching materials include power points. Teaching materials used are in accordance with the curriculum but in the teaching materials students have not been able to design and develop their creativity in making the correct biology learning media, so the students did not have the skilled to produce the biology media learning.

The Available of biology learning media modules from the results of data analysis that has been obtained showed that, biology learning media modules are not yet available in this assessment learning from lecturers and from students. The 
results of the data obtained the percentage of module readiness from lecturers $0 \%$ and from students $32.5 \%$. This proved that the module is not yet available and it has not been used in learning. The modules form teaching materials, are packaged intact, systematic, and contain asset of planned learning experiences and it are designed to help students get specific learning goals [14]. The function module to be a teaching material that is able to make active and creative students both in independent and group work. The module can help students in independent and group learning. The module is also equipped with questions and answer keys, so students can improve their own abilities without having to wait for training from the lecturer. In accordance with the opinion of Kiong [15], using modules can also be an alternative approach by students in solving learning problems. This is because the module can make students learn independently. The module can also be used as a media for learning at home by students so that students can also be creative and motivate to learn at home, because learning media can overcome the limitations of space and time in learning [2]. According to Thoifuri [16] learning media help the students more quickly know, understand and skilled efforts in studying certain fields of study, both media in the form of hardware (software) and software (software).

The analysis results in the desire to make modules from lecturers and students are also very high, with percentage are $100 \%$ and $97.5 \%$, this happens indeed infact lecturers have not used modules in the lectures on biology learning media. The teaching materials used by lecturers have only been in the form of power points. The power point used is of course only an important point. This has not been able to help students develop their creativity in producing a suitable media for material that is in biology. The lecturers and students want to make a special module on biology learning media. When viewed from its usefulness the module is also able to make student learning out comes increase. Modules can be interpreted as teaching materials derived from the basic competencies contained in the curriculum and arranged systematically written with the aim that learners can learning dependently without teacher guidance [3].

The aspects of the Based Learning Project presented in the module both lecturers and students strongly support this. Because the results of the assessment obtained are $100 \%$ of lecturers and $82.5 \%$ of students. Project-based learning according to Aisyi, et. al., [17] is a learning model that aims to encourage students to solve real problems and be able to produce products to solve these problems. The Project Based Learning model is a learning model that is suitable for use in process learning that emphasizes student activity, providing freedom to develop their potential. Overall results indicate that modules are needed [9]. This result it same with Lasuaskiene and Vaite [18] the PPA application can make students apply theoretical knowledge and skills in their practice. So that it can improve students' skills.

\section{Conclusion}

The results showed that the average value of student needs for Project Based-Learning learning media module with criteria absolutely high need. It can be concluded that students have need a Project Based-Learning module in learning. Its mean too that using the module based on Project Based-Learning at learning can improve the motivation, and understanding student to the lesson topics.

\section{Acknowledgements}

We would like to thank to Minister of Kementerian Riset, Teknologi, dan Pendidikan Tinggi whom has supported, and funded of thisresearch.

\section{References}

[1] Mukti and Nurcahyo. 2017. Pengembangan media pembelajaran biologi berbantuan computer untuk meningkatkan hasil belajar peserta didik. Jurnal Inovasi Pendidikan IPA. Vol 3 No. 2.

[2] Athiyah, Ummi. 2018. Pengembangan Media Pembelajaran Biologi Semester II Kelas X SMA Berbasis Lectora Inspire. Jurnal Nalar Pendidikan. Vol 6, No 1.

[3] Prastowo, A. 2011. Panduan Kreatif Membuat Bahan Ajar Inovatif. Yogyakarta: DIVA Press.

[4] Sumarmin, Ramadhan, dkk. (2014)."Pengembangan Modul Pembelajaran Biologi dengan Pendekatan Contextual Teaching and Learning (CTL) yang Dilengkapi Peta Konsep untuk SMA Kelas XI" Jurnal Kolaboratif. Vol. 2 No. 1.

[5] Nawawi, Sulton. 2017. Developing of Module Challenge Based Learning in Environmental Material to Empower the Critical Thinking Ability. Jurnal Inovasi Pendidikan IPA, 3 (2), 2017, 212-223.

[6] Daryanto. 2013. Menyusun Modul Bahan Ajar Untuk Persiapan Guru Dalam. Mengajar. Yogyakarta: Gava Media.

[7] Mahanal, Susriyanti et al. 2010. Pengaruh Pembelajaran Project Based Learning (PjBL) pada Materi Ekosistem terhadap Sikap dan Hasil Belajar Siswa SMAN 2 Malang. Bioedukasi pendidikan biologi. Vol 1no. 1. 2010.

[8] Permadi. 2018. Pengembangan Modul E-Learning Berbasis Project Based Learning (PjBL) Pada Mata Kuliah Media Pembelajaran Fisika. Jurnal Ilmu Fisika dan Pembelajarannya (JIFP), Vol. 2, No. 2, Desember 2018, 1-12.

[9] Ismuwardani et. al. 2019. Implementation of Project Based Learning Model to Increased Creativity and Self-Reliance of Students on Poetry Writing Skills. Journal of Primary Education 8 (1) (2019): 51-58.

[10] Maiasputri, Nike et al. 2018. The Validity of the Development of Project-Based Oriented Learning Modules on Evolution and Biotechnology Materials For High School. International Journal of Progressive Sciences and Technologies (IJPSAT). Vol. 6 No. 2 January 2018, pp. 433-438. 
[11] Sophia, A. 2017. Pengembangan Penuntun Praktikum Taksonomi Invertebrata Berbasis Pendekatan Saintifik untuk Mahasiswa. Tesis. Universitas Negeri Padang: Padang.

[12] Riduwan, 2010. Belajar Mudah Penelitian. Bandung: Alfabeta.

[13] Riduwan, dan Akdon, 2013. Rumus dan Data Dalam Analisis Statistika. Bandung. Alfabeta.

[14] Hasanah et al, 2018. Pengembangan Modul Suhu Dan Kalor Berbasis Project Based Learning Untuk Meningkatkan Keterampilan Proses Sains Dan Kemampuan Berpikir Kritis Siswa SMA/MA. Jurnal Pendidikan (Teori dan Praktik). Volume 3 No1. p 38-44.
[15] Kiong, T, et al. 2011. The Development And Evaluation Of The Qualitis Of Buzan Mid Mapping Module. ProcediaSocial and Behavioral Sciences. Universiti Tun Hussein Onn Malaysia.

[16] Thoifuri. 2008. Menjadi Guru Inisiator. Semarang: RASAIL.

[17] Aisyi, F. et al. 2013. Pengembangan Bahan Ajar TIK SMP Mengacu pada Pembelajaran Berbasis Proyek. Invotec. Vol. IX. (2): 117-128.

[18] Lasuaskien and Rauduvaite. 2015. Project-Based Learning at University: Teaching Experiences of Lecturers. ProcediaSocial and Behavioral Sciences. 197 (2015) 788-792. 